DESERT NAVIGATOR 



\section{Desert Navigator}

\section{THE JOURNEY OF AN ANT}

\section{Rüdiger Wehner}

THE BELKNAP PRESS OF HARVARD UNIVERSITY PRESS

Cambridge, Massachusetts, and London, England 2020 
Copyright () 2020 by the President and Fellows of Harvard College All rights reserved

Printed in Canada

First printing

Cover art: Cataglyphis bombycina, the silver ant. (C) Rüdiger Wehner Cover design: Annamarie MacMahon Why

9780674247925 (EPUB)

9780674247932 (MOBI)

9780674247918 (PDF)

The Library of Congress has cataloged the printed edition as follows:

Names: Wehner, Rüdiger, author.

Title: Desert navigator : the journey of an ant / Rüdiger Wehner. Description: Cambridge, Massachusetts : The Belknap Press of Harvard

University Press, 2020. | Includes bibliographical references and index. Identifiers: LCCN 2019015093 | ISBN 9780674045880 (hardcover) Subjects: LCSH: Ants-Behavior-Sahara. | Animal navigation. | Neural circuitry. Classification: LCC QL568.F7 W427 2020 | DDC 595.79/6156-dc23

LC record available at https://lccn.loc.gov/2019015093 
For Sibylle 
